\title{
A radical treatment for surfer's eye
}

\author{
Thomas Gordon Campbell ${ }^{1,2}$
}

${ }^{1}$ School of Medicine, University of Queensland, Brisbane, Queensland, Australia

2Princess Alexandra Hospital, Brisbane, Queensland, Australia

\section{Correspondence to} Dr Thomas Gordon Campbell, thomasgordoncampbell@gmail. com

Accepted 4 March 2014

\section{DESCRIPTION}

In the world of surfing, a pterygium-a band of fibrous tissue that extends from the conjunctival surface on to the cornea-is common enough have acquired the moniker 'surfer's eye'. Pterygia can encroach on the visual axis or cause a foreign body sensation in the eye, at which stage surgical removal of the pterygium and coverage of the area with a conjunctival auto-graft is recommended.

Waimea Bay in Hawai'i is the undisputed epicentre of big wave surfing. Waves at 'The Bay' can exceed $15 \mathrm{~m}$ in height and surfers can reach speeds of $70 \mathrm{kph}$. Early in 2013, a 61-year-old extremely experienced surfer, with a long history of a pterygium extending onto his corneal surface, overbalanced while surfing a $\sim 10 \mathrm{~m}$ wave at Waimea Bay.
He momentarily dipped his face into the water while travelling at top speed (figure 1), but was able to recover his balance and continue surfing the wave. This impressive manoeuvre resulted in the pterygium being ripped off his eye surface (figure 2). The corneal component was cleared and his visual and foreign body sensation symptoms improved. Although the wound site was inflamed for several days, it ultimately recovered without medical intervention. To my knowledge, this is the first recorded instance of such an unconventional approach to dealing with 'surfer's eye'. As of June 2013, the pterygium had not returned. The author has recommended that if it does return, the surfer should seek a more traditional method of pterygium removal through his nearest ophthalmologist.

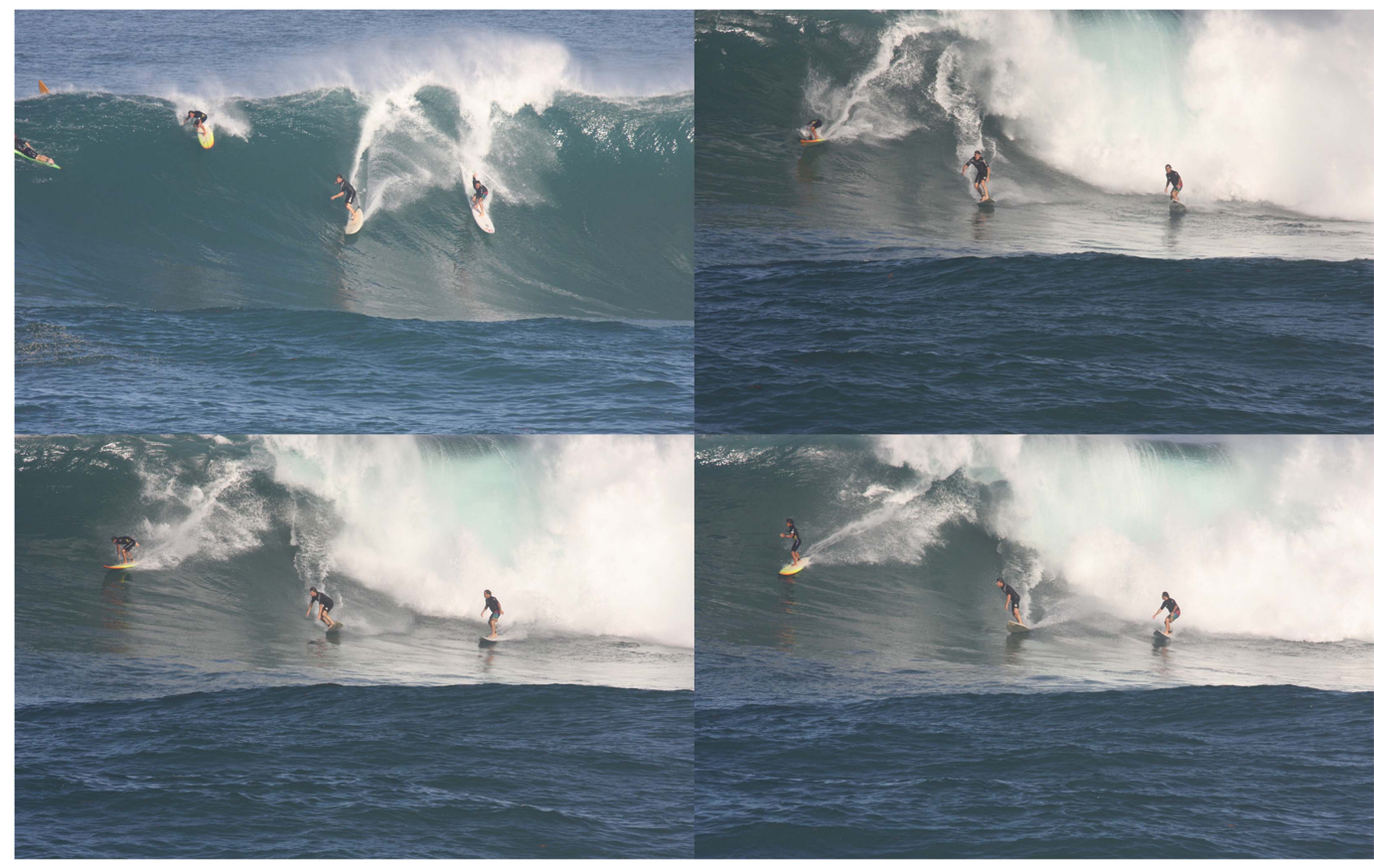

Figure 1 The surfer (top left on yellow and red board) overbalancing while surfing a $\sim 10 \mathrm{~m}$ wave at Waimea Bay. He momentarily dipped his face into the water while travelling at top speed but was able to recover his balance and continue surfing the wave. 


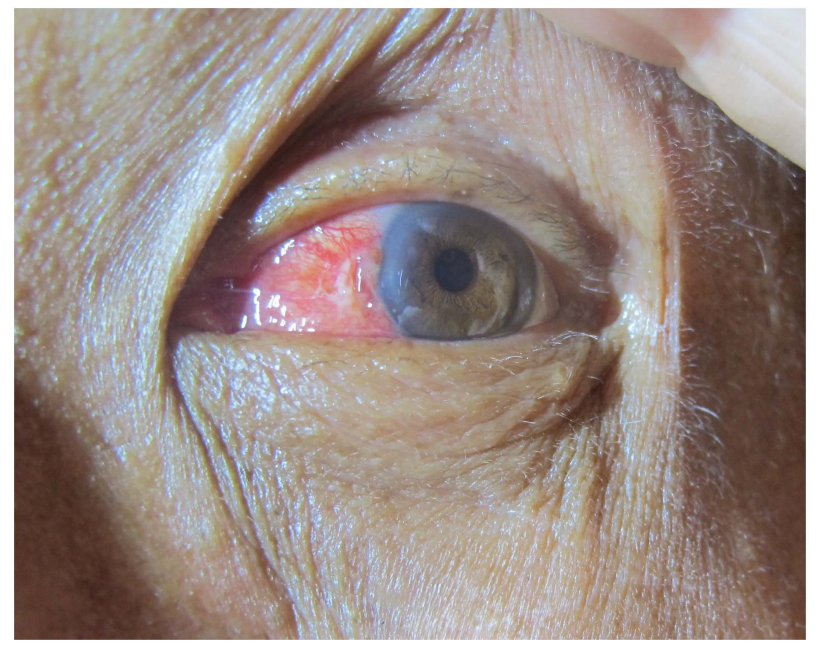

Figure 2 The surfer's eye 3 days after injury with clearance of the corneal component of the pterygium and mild local inflammation.

\section{Learning points}

- Pterygium are an occupational hazard for surfers and others who spend inordinate amounts of time in the sun.

- The high speeds attained in big-wave surfing, and the sharply pointed surfboards used, predispose riders to a variety of injuries, including ophthalmic injuries.

- Pterygia, "wing of flesh", are a benign fibrovascular proliferation that arises from the conjunctiva and extends onto the cornea. They can cause a foreign body sensation, irritation, and can cause visual disturbances by distorting the cornea or occluding the visual axis.

Acknowledgements TGC would like to thank Andrew Stark and Dennis Pang for bringing this case to his attention and for the use of their photos in the article.

Competing interests None.

Patient consent Obtained.

Provenance and peer review Not commissioned; externally peer reviewed.

Copyright 2014 BMJ Publishing Group. All rights reserved. For permission to reuse any of this content visit http://group.bmj.com/group/rights-licensing/permissions.

BMJ Case Report Fellows may re-use this article for personal use and teaching without any further permission.

Become a Fellow of BMJ Case Reports today and you can:

- Submit as many cases as you like

- Enjoy fast sympathetic peer review and rapid publication of accepted articles

- Access all the published articles

- Re-use any of the published material for personal use and teaching without further permission

For information on Institutional Fellowships contact consortiasales@bmjgroup.com

Visit casereports.bmj.com for more articles like this and to become a Fellow 